\title{
GEOCHEMISTRY ANALYSIS OF GROUNDWATER QUALITY: A CASE STUDY OF THE JEUNIB BASIN
}

\author{
Muhammad Irham ${ }^{1,2,} \bowtie$, Muhammad $\operatorname{Irpan}^{3}$, Dewi Sartika ${ }^{3}$, Gartika Setiya \\ Nugraha $^{3}$ and Dian Budi Dharma ${ }^{4}$ \\ ${ }^{1}$ Geographical Information Systems Laboratory, Faculty of Marine and Fisheries, \\ Universitas Syiah Kuala, Indonesia \\ ${ }^{2}$ Center for Environmental and Natural Resources Research (PPLH-SDA), Universitas Syiah \\ Kuala, Indonesia \\ ${ }^{3}$ Geology Engineering Study of Earth Science Engineering Department, Universitas Syiah Kuala, \\ Indonesia \\ ${ }^{4}$ Energy and Mineral Resources Agency of Aceh Province, Indonesia \\ ${ }^{\square}$ Corresponding Author: irham@unsyiah.ac.id
}

ABSTRACT

Groundwater quality depends on many things, one of which is the condition of the rock lithology. To determine the quality of groundwater, a geological survey and mapping were carried out through interpretation of the outcrops found in the field; then several groundwater quality parameters were measured and analyzed. This study aims to determine the quality of groundwater by analyzing the parameters of nitrate, phosphate, total dissolved solids (TDS), temperature, $\mathrm{pH}$, turbidity, chloride, manganese $(\mathrm{Mn})$, iron $(\mathrm{Fe})$, and electrical conductivity (EC). The groundwater quality parameters were weighted and calculated using the National Sanitation Foundation Water Quality Index (NSFWQI) method. Geologically, the groundwater aquifer in the study area exists in an alluvium unit with a coastal alluvial sediment type of aquifer system confined with $\mathrm{Ca}-\mathrm{HCO}_{3}$ and $\mathrm{Mg}-\mathrm{SO}_{4}$ facies aquifer. Meanwhile, groundwater quality is categorized as moderate, good, and excellent. The moderate category was TSB 6 , the good category was TSB 1 , TSB 7, and TSB 8; while the excellent category was at TSB 2, TSB 3, TSB 4, TSB 5, and TSB 9.

Keywords: Geochemistry Analysis, Groundwater Quality, Groundwater Facies, Rock Lithology, Rock Outcrop.

RASĀYAN J. Chem., Vol. 14, No.4, 2021

\section{INTRODUCTION}

Water is one of the life supports for living things, especially humans because without water there would be no life. ${ }^{1}$ Currently, it is not only the problem of water quantity that needs attention ${ }^{2,3}$ but also the problem of water quality. ${ }^{4-6}$ The availability and quality of water are important parts of nature that need to be maintained. Water quality is highly dependent on many things such as human activities ${ }^{7,8}$, climate change ${ }^{9,10}$, and rock lithology conditions. ${ }^{11-13}$

According to Indonesian Energy and Mineral Resources, Indonesia has 421 Groundwater Basins (GWB), ${ }^{14}$ one of which is GWB Jeunib in Pidie Jaya and Bireun districts. ${ }^{15}$ GWB Jeunib is located at the coordinates $96^{\circ} 11$ '54.82"- 96 34"56.13" East Longitude and 5 8"4.72" - 5 15 "49.44" North Latitude with an area of $310 \mathrm{~km}^{2}$. Administratively, GWB Jeunib borders Bireun Regency in the east, the Malacca Strait in the north, Trienggadeng District in the west, and Meureudu District in the south. This research was conducted limited to Ulim District, Meureudu District, Meurah Dua District, Term Buya and Bandar Dua District, which are located in GWB Jeunib, Pidie Jaya Regency.

As support for human life, water is very much determined by its quality. ${ }^{16,17}$ There are nine (9) mandatory parameters in determining water quality, namely Biological Oxygen Demand (BOD), Dissolved Oxygen (DO), nitrate, total phosphate, Total Dissolved Solid (TDS), temperature changes, $\mathrm{pH}$, turbidity, and Faecal Coliform. ${ }^{18}$ Meanwhile, two more parameters namely, cuprum $(\mathrm{Cu})$ and Cadmium $(\mathrm{Cd})$ were added. ${ }^{19}$ However, in this study, the parameters of DO, FC, BOD, temperature change and TS were replaced and modified into other parameters such as the solubility of manganese $(\mathrm{Mn})$, iron $(\mathrm{Fe})$, chloride, sulphate ions, Electrical Conductivity (EC), and TDS.

Rasayan J. Chem., 14(4), 2327-2339(2021)

http://doi.org/10.31788/RJC.2021.1446454

This work is licensed under a CC BY 4.0 license. 
Furthermore, water quality is influenced by the existing rock lithology factors. ${ }^{20,21}$ Information about the lithology of these rocks can be found on a geological map. ${ }^{22,23}$ Geological maps are obtained by observing directly the rock outcrops that are scattered in the research location. ${ }^{24}$ This mapping is very important to know. There is a suitability of the relationship between rock lithology and groundwater chemistry data and groundwater quality. ${ }^{25,26}$

The source of groundwater that is widely used by the people of Jeunib is shallow groundwater and is dominant in the alluvial sedimentary type. ${ }^{15}$ The groundwater is the main source of freshwater reserves which work in the hydrostatic cycle. ${ }^{27}$ However, the use of groundwater for human consumption and irrigation in the last decade has resulted in a decrease in the quality and quantity of groundwater. ${ }^{28-30}$ Therefore, the quality of groundwater that is suitable for consumption as drinking water must be tested for physical, chemical, microbiological parameters, and radio activation. ${ }^{31,32}$ Meanwhile, groundwater conditions are important for humans, especially the current conditions which are exacerbated by pollution, urbanization, and industrialization. ${ }^{33,34}$ Therefore, to determine the condition of groundwater in the Jeunib Basin, geochemical analysis of water quality is needed.

Until now, research on the groundwater quality of the Jeunib Basin has never been carried out. Since the need for water in this area is greatly urgent and the availability of surface water is limited, the one way is using shallow groundwater that is easily accessible to the people in this area. To determine the quality and potential of groundwater pollution that occurs due to population activities in this area, research on geochemical analysis of water quality in the Jeunib basin area is crucial. Therefore, this study aims to analyze the geochemistry of groundwater quality of Jeunib basin by employing the parameters of nitrate, phosphate, total dissolved solids (TDS), temperature, $\mathrm{pH}$, turbidity, chloride, manganese ( $\mathrm{Mn})$, iron (Fe), and electrical conductivity (EC). The methods used in this study include geological survey and mapping by interpreting the outcrops in the field, then measuring several groundwater quality parameters in 9 bore wells in the Jeunib area.

\section{Study Area}

This study was conducted in GWB Jeunib which is located between five Districts of Pidie Jaya Regency with an area of $60 \mathrm{~km}^{2}$. Jeunib basin is bounded in a mapping block of $60 \mathrm{~km}^{2}$. Geographically, the mapping location is at the coordinates of $96^{\circ} 14^{\prime} 30.48^{\prime \prime}-96^{\circ} 19^{\prime} 06.91^{\prime \prime}$ East and $5^{\circ} 11^{\prime} 29.6^{\prime \prime}-5^{\circ} 15^{\prime} 18.18^{\prime \prime}$ North as shown in Fig.-1.

\section{Groundwater Sampling}

The groundwater sampling was carried out in 9 predetermined locations which are the areas of resident boreholes. The study locations are shown in Table-1 and Fig.-2. After the groundwater sample was obtained, chemical and physical analyses were carried out in the laboratory. The chemical and physical parameters of groundwater analyzed were $\mathrm{pH}, \mathrm{EC}$, manganese, iron, nitrate, turbidity, TDS, chloride, sodium, potassium, calcium, chloride, and sulfate. These parameters were analyzed using the NSF-WQI analysis method.

\section{NSF-WQI Analysis Method}

The research method used in this study is the groundwater quality analysis method. In the analysis, the groundwater quality index uses the NSF-WQI method to determine the status of groundwater quality. For groundwater quality analysis, the first step is to take groundwater samples in the field based on the results of a geological study. Analysis of water quality parameters was carried out in the laboratory.

This stage was carried out by collecting data on chemical and physical parameters in the form of sulfate, $\mathrm{pH}, \mathrm{EC}$, manganese, iron (Fe), nitrate, turbidity, TDS, and chloride from water samples in the wells. Sampling was carried out in the scope of the mapping area in Ulim, Meureudu, Meurah Dua, Jangka Buya and Bandar Dua District. Measurement of groundwater quality samples was carried out in boreholes in the Jeunib basin. The research location points through satellite images can be seen in Fig.-2, while the locations of each borehole point can be seen in Table-1. 
RASĀYAN J. Chem.

Vol. 14 | No. 4 |2327-2339| October- December | 2021

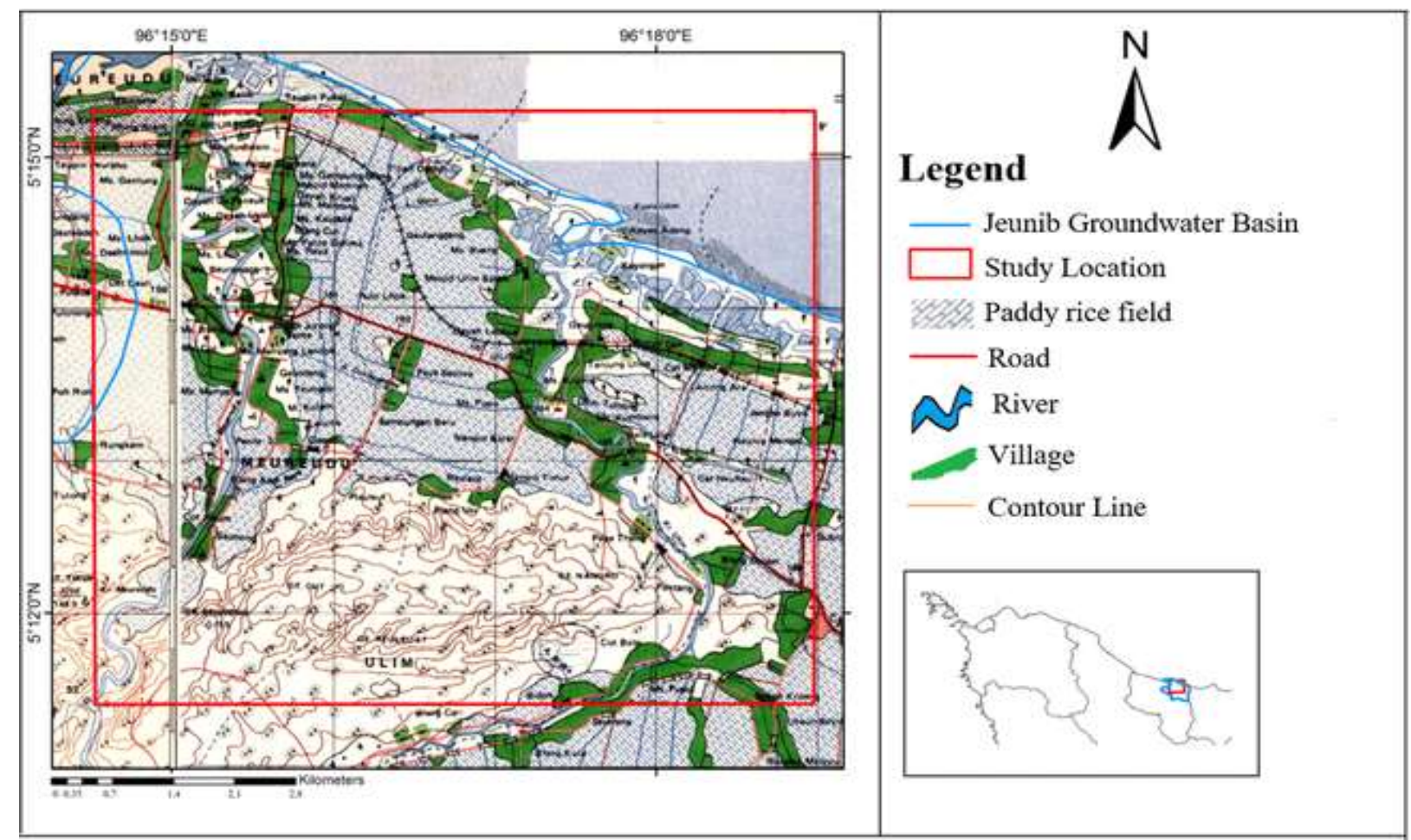

Fig.-1: Map of the Study Area

To calculate the status of groundwater quality, the National Sanitation Foundation Water Quality Index method was employed by using the following equation: ${ }^{35}$

Where:

$$
W Q I=\frac{\sum_{i=1}^{n} W_{i} Q_{i}}{\sum_{i-1}^{n} W_{i}}
$$

Wi: the weight assigned to each parameter.

Qi: The sub-index value for each parameter

Table-1: Location of the Groundwater Sampling

\begin{tabular}{c|c|l}
\hline No. & Sampling Point & \multicolumn{1}{c}{ Sampling Area } \\
\hline 1 & TSB 1 & Masjid At- Taqwa Gp Meunasah Balek, Meureudu \\
\hline 2 & TSB 2 & Dayah Al - Hijrah Gp. Masid Tuha, Meureudu \\
\hline 3 & TSB 3 & Meunasah Lhok, Meureudu \\
\hline 4 & TSB 4 & RSUD Meureudu, Meureudu \\
\hline 5 & TSB 5 & Dayah Fathul Ainiyah Al Aziziah, Meureudu \\
\hline 6 & TSB 6 & Gp Meunasah Bueng, Ulim \\
\hline 7 & TSB 7 & Gp Pulo Ulim, Ulim \\
\hline 8 & TSB 8 & Gp. Ule Glee, Bandar Dua \\
\hline 9 & TSB 9 & Meunasah Pulo Baroh, Bandar Dua \\
\hline
\end{tabular}

Wi is the weight given to each parameter as can be seen in Table-2. While the value of Qi is the value determined by the sub-index graph for each parameter as can be seen in Fig.-3 sub-index values for several parameters ${ }^{36,37}$ such as sulphate, EC, iron (Fe), and chloride. These sub-indexes refer to the Global Drinking Water Quality Index Development and Sensitivity Analysis Report and A New Quality Index for Bottled Water Assessment. ${ }^{38}$ While other parameters such as $\mathrm{pH}$, temperature changes, nitrates, turbidity, and TDS refer to the parameters contained in the National Sanitation Foundation Water Quality Index. ${ }^{39}$ After obtaining the NSF-WQI score, then the sample was given the groundwater feasibility index category as shown in Table-3. 
RASĀYAN J. Chem.

Vol. 14 | No. 4 |2327-2339| October-December | 2021

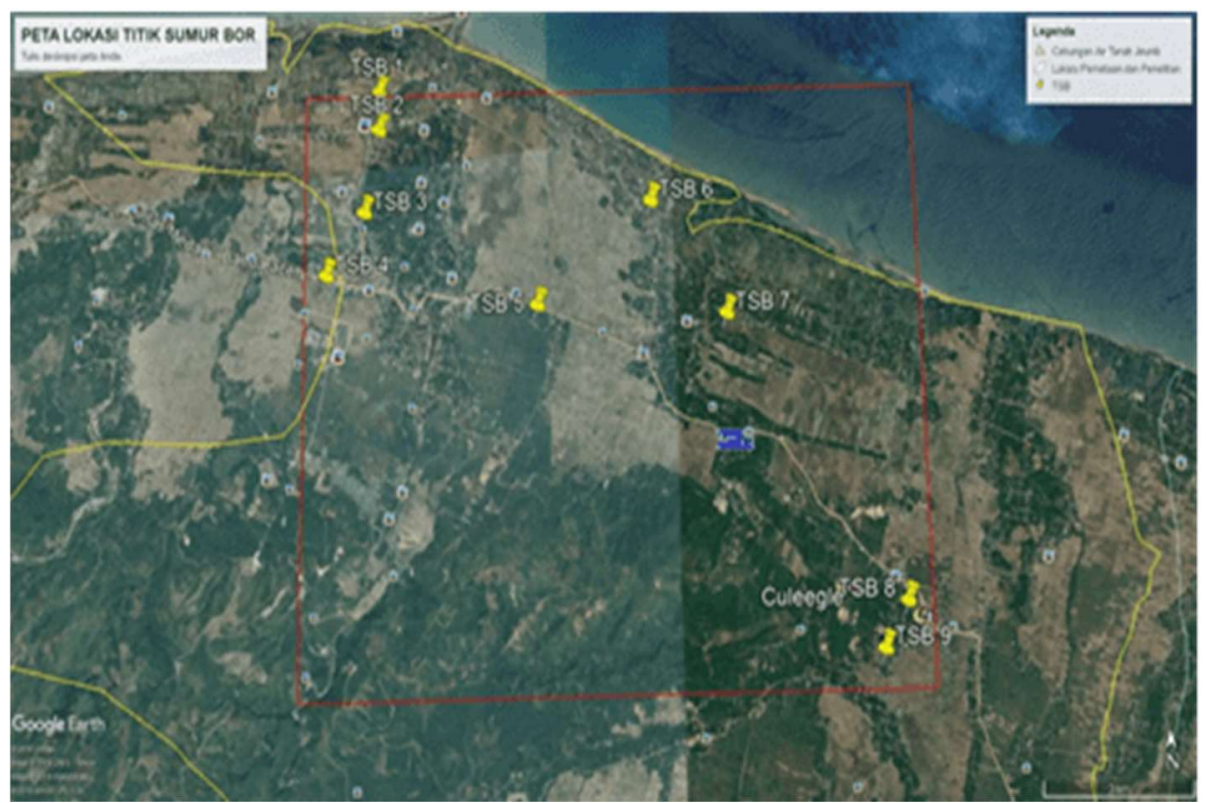

Fig.-2: Location of Groundwater Sample Points for Study Site

Table-2: Weight Value of Each Parameter (Wi)

\begin{tabular}{c|c|c}
\hline No & Parameter & $\begin{array}{c}\text { The Weight } \\
(\mathrm{Wi})\end{array}$ \\
\hline 1. & Sulphate & 0.17 \\
\hline 2. & $\mathrm{pH}$ & 0.11 \\
\hline 3. & EC & 0.11 \\
\hline 4. & Mangan & 0.10 \\
\hline 5. & Iron (Fe) & 0.10 \\
\hline 6. & Nitrate & 0.10 \\
\hline 7. & Turbidity & 0.08 \\
\hline 8. & TDS & 0.07 \\
\hline 9. & Chloride & 0.16 \\
\hline \multicolumn{2}{|c|}{ Total Weight (Wi) } & 1.00 \\
\hline \multicolumn{2}{l}{}
\end{tabular}

Table-3: Categories of Water Quality Index (NSF-WQI)

\begin{tabular}{c|c}
\hline NSF-WQI Score & Category \\
\hline $0-25$ & Very bad \\
\hline $26-50$ & Bad \\
\hline $51-70$ & Moderate \\
\hline $71-90$ & Good \\
\hline $91-100$ & Excellent \\
\hline
\end{tabular}

\section{NSF WQI Analysis}

\section{RESULTS AND DISCUSSION}

Groundwater is static and not influenced by fluctuations in seasonal changes and human activity. It is only influenced by the interaction of groundwater flow with the rocks it passes through and seawater intrusion. The NSF-WQI analysis in this study was conducted to assess the chemical quality of groundwater as raw material for drinking water based on Indonesian national standards. In this analysis, nine groundwater parameters were tested to assess the quality of drinking water raw materials consisting of manganese, iron, $\mathrm{pH}$, sulphate, chloride, electrical conductivity, nitrate, turbidity, and the number of dissolved solids. The analysis results are described in the following parameters:

\section{Manganese $\left(\mathrm{Mn}^{2+}\right)$}

The $\mathrm{Mn}^{2+}$ content in several wells at the research location can be seen in Fig. 4 . The $\mathrm{Mn}^{2+}$ content had a concentration value range between $0.01-70 \mathrm{mg} / \mathrm{l}$ with an average concentration value of $1.54 \mathrm{mg} / \mathrm{l}$. Six samples had a concentration value of $\mathrm{Mn}^{2+}$ above the maximum tolerance limit, these locations were found at TSB-1, TSB-2, TSB-3, TSB-6, TSB-7, and TSB-8, while those that met the standards were TSB-4, TSB5, and TSB-9.

Manganese is present in complex forms and is generally found in bicarbonate rocks and organic materials such as $\mathrm{Mn}(\mathrm{OH})_{2}$ and $\mathrm{MnCO}_{2}$, which are relatively difficult to dissolve in water. However, several other manganese salt compounds such as $\mathrm{MnSO}_{4}, \mathrm{MnCl}_{2}$ and $\mathrm{Mn}\left(\mathrm{NO}_{3}\right)_{3}$ have large solubility in water. ${ }^{41}$ 
RASĀYAN J. Chem.

Vol. 14 | No. 4 |2327-2339| October- December | 2021
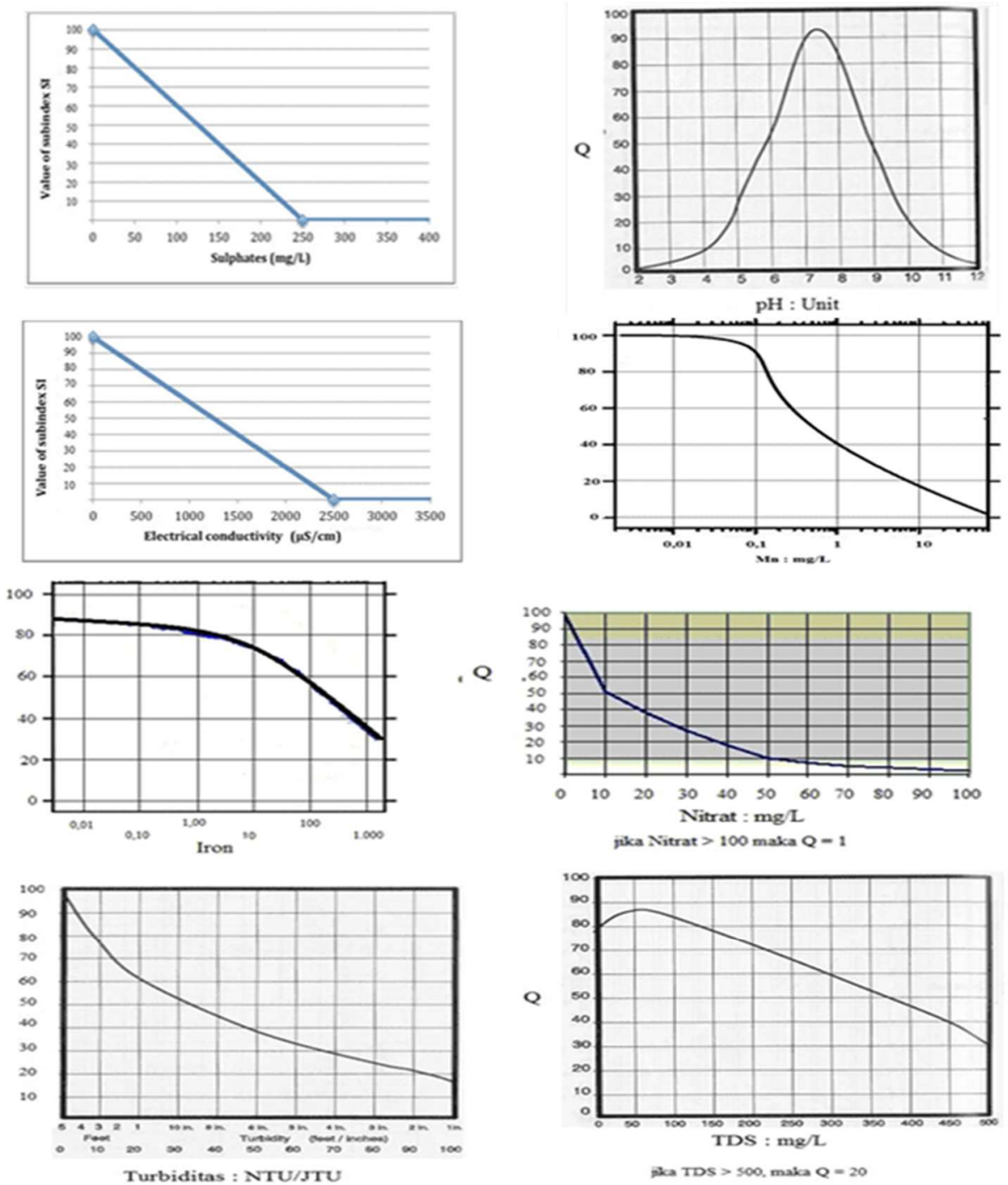

jika Nitrat $>100$ maka $Q-1$
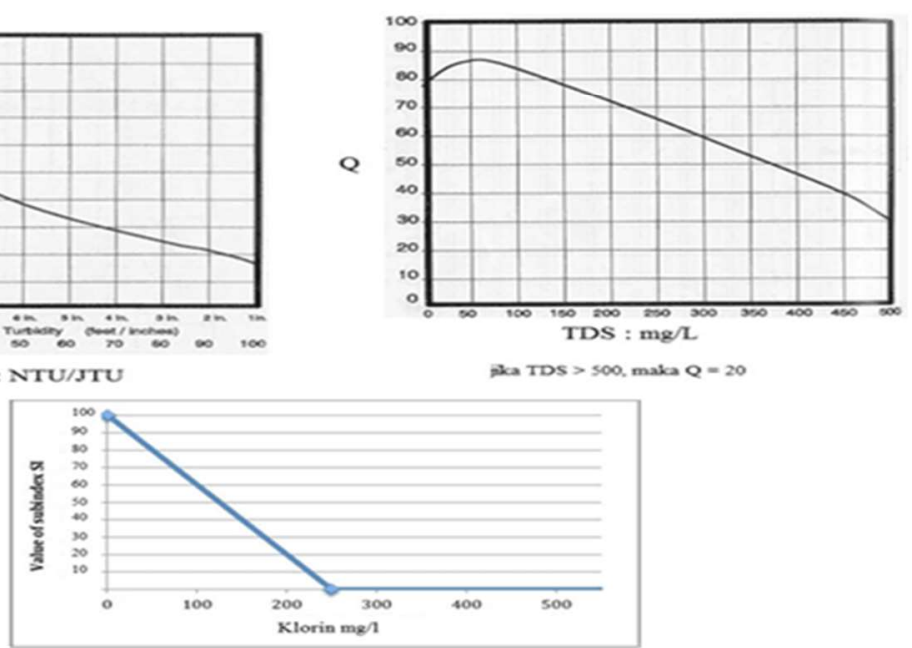

Fig.-3: Sub-index Values for (a) Sulfate, (b) pH, (c) EC, (d) Temperature Change, (e) Iron (Fe), (f) Nitrate, (g) Turbidity, (h) TDS, (i) Chloride ${ }^{29,40}$

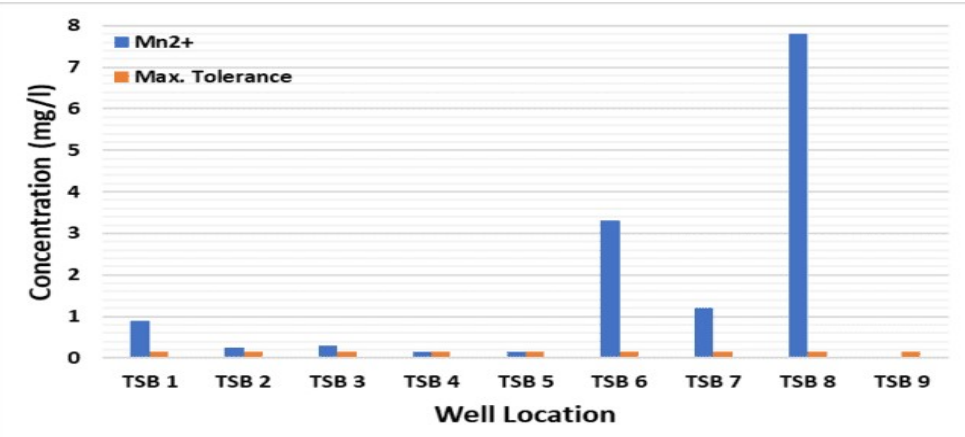

Fig.-4: Results of Analysis of Manganese $\left(\mathrm{Mn}^{2+}\right)$ Concentration at the Study Site 


\section{Iron $\left(\mathrm{Fe}^{2+}\right)$}

The results of the analysis of the concentration of $\mathrm{Fe}^{2+}$ in several wells at the research location can be seen in Fig.-5. The $\mathrm{Fe}^{2+}$ content in the wells at the research location ranged from 0.06 to $0.20 \mathrm{mg} / \mathrm{l}$ with an average concentration of $0.18 \mathrm{mg} / \mathrm{l}$. In this study, two drilled wells were not tested for $\mathrm{Fe}^{3+}$ content, so that they did not have a value for the concentration of $\mathrm{Fe}^{2+}$. All TSBs that were carried out in lab tests showed that the $\mathrm{Fe}^{2+}$ content in these locations contained $\mathrm{Fe}^{3+}$ concentration below the specified maximum tolerance value.

Iron is one of the metals most often found in water. Iron with a high level of more than $1.00 \mathrm{mg} / \mathrm{l}$ can cause the water to turn reddish, gives water an unpleasant taste, and cause stains on equipment and materials exposed to the water. ${ }^{42}$ If the water is consumed continuously for a long time, it will cause kidney damage and even death. ${ }^{43}$ The maximum concentration of $\mathrm{Fe}^{2+}$ determined according to the Indonesian national standard is $0.30 \mathrm{mg} / \mathrm{l}$.

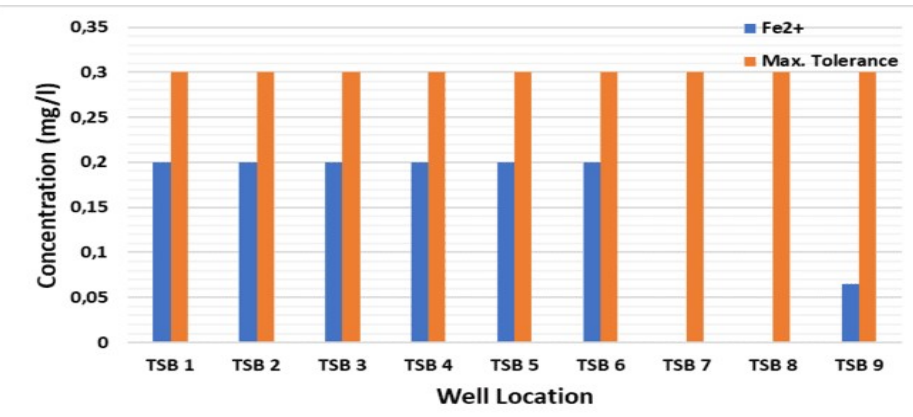

Fig.-5: Concentrations of Fe Content in the Study Sites were analyzed based on the NSF WQI Method

\section{pH}

The results of groundwater $\mathrm{pH}$ measurements in boreholes at the research location showed a $\mathrm{pH}$ value in the range of 6.2-7.6 with an average $\mathrm{pH}$ value of 7.08. The $\mathrm{pH}$ range value determined according to Indonesian standards is 6.5-8.5. The results of the analysis of $\mathrm{pH}$ values in several wells at the research location can be seen in Fig.-6. There was 1 well that did not meet Indonesian standards, namely at TSB 6 with a $\mathrm{pH}$ value of 6.1 , while the other TSBs were in the range of $\mathrm{pH}$ values which are still considered fit for consumption.

The $\mathrm{pH}$ in the water shows the level of hydrogen ions in the water. The $\mathrm{pH}$ value is influenced by several chemical and biochemical reactions. If the water consumed in the human body has a $\mathrm{pH}$ of water that does not meet the standard, certain chemical reactions in the body can occur which can turn it into poison for humans. ${ }^{44}$

\section{Sulphate ( $\left.\mathrm{SO}_{4}{ }^{2-}\right)$}

The maximum tolerance for the concentration of $\mathrm{SO}_{4}{ }^{2-}$ is stipulated as raw material for drinking water according to the Indonesian national standard. At the research location, all TSBs showed that the sulphate concentration was still below the maximum tolerance value ranging from $0.01-70 \mathrm{mg} / 1 \mathrm{with}$ an average concentration of $18.22 \mathrm{mg} / \mathrm{l}$ (Fig.-7).

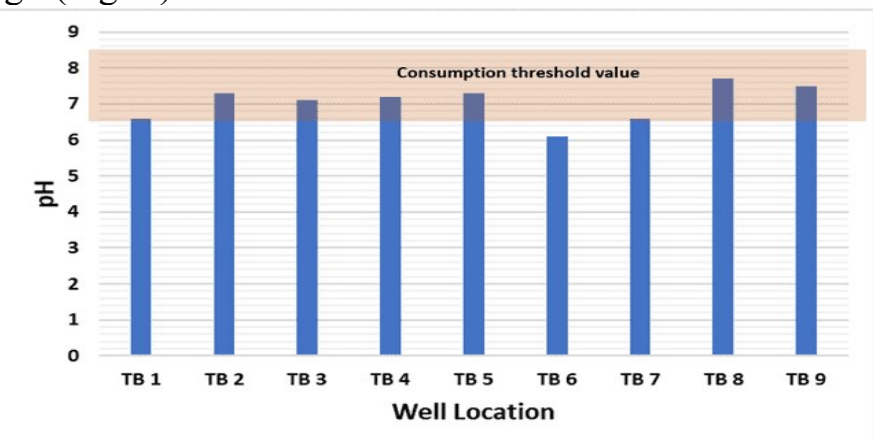

Fig.-6: The Results of the Analysis of the pH Value at the Study Site 
In non-polluted water bodies, such as groundwater or confined aquifers, sulphate concentrations are generally low and less than $30 \mathrm{mg} / \mathrm{l}$. However, in some cases of unpolluted groundwater, the $\mathrm{SO}_{4}{ }^{2-}$ concentration can reach $100 \mathrm{mg} / \mathrm{l}$ if the groundwater passes through rocks that are rich in gypsum minerals. In addition, too high sulphate concentrations in the water have a pathogenic effect on the human body. ${ }^{45}$

\section{Chloride ( $\left.\mathrm{Cl}^{-}\right)$}

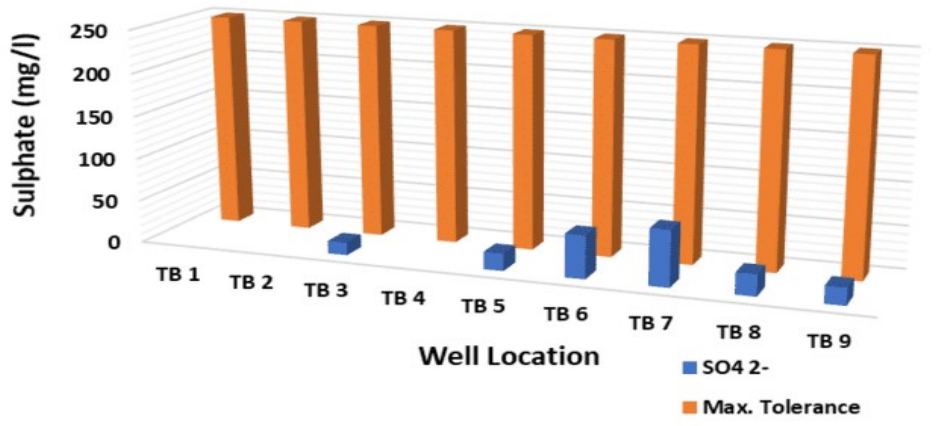

Fig.-7: The Results of the Analysis of the Sulphate Concentration at the Study Site

The chloride concentration in the borehole in the study area is shown in Fig.-8. The chloride concentration level stipulated by the Indonesian government is $250 \mathrm{mg} / \mathrm{l}$. The results show that the chloride concentrations in all TSB ranged from 0.01 to $71 \mathrm{mg} / 1$ with an average of $9.27 \mathrm{mg} / 1$ and were below the maximum tolerance specified. Most of the chloride comes from sediments and occurs in nature with varying concentrations ${ }^{46}$. Chloride concentrations can increase as mineral levels increase and usually the groundwater is close to the sea or used to be marine environment. ${ }^{46}$

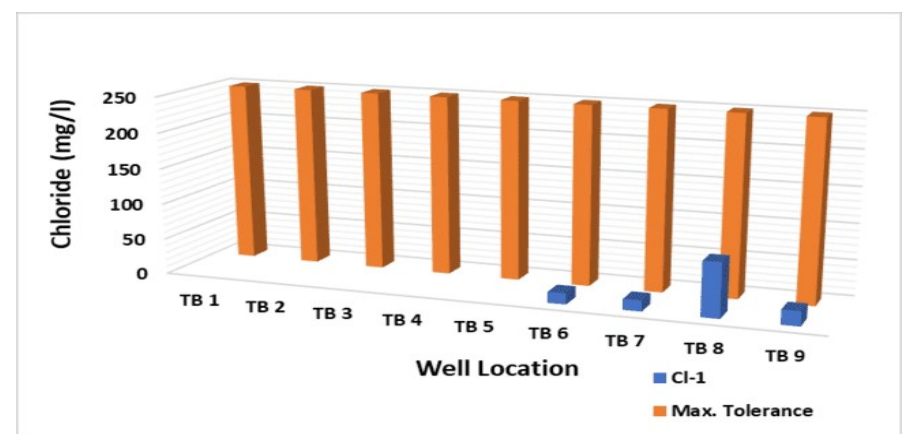

Fig.-8: Results of Analysis of Chloride Concentrations at the Study Site

\section{Electrical Conductivity}

In the study area, there was one well that had a conductivity value above the maximum tolerance, i.e., TSB6 with an electrical conductivity value of $5787 \mu \mathrm{s} / \mathrm{cm}$. Based on research results on TSB-7, although the conductivity value was below the maximum tolerance value of $2011 \mu \mathrm{s} / \mathrm{cm}$ (Fig.-9), the water was no longer suitable for consumption because there was an indication that the water tasted no longer fresh and smelled bad. $^{47}$

Electrical conductivity is the ability of water to continue or carry electricity. The conductivity here indicates that the more dissolved mineral salts, the higher the electrical conductivity value. ${ }^{48}$ The tolerance limit for electrical conductivity allowed by the Indonesian government is $2250 \mu \mathrm{s} / \mathrm{cm}$. The higher the value of the electrical conductivity of the water, the higher the level of salinity of the water.

\section{Nitrate $\left(\mathrm{NO}^{3-}\right)$}

Figure-10 shows that the nitrate concentration in all boreholes was below the maximum tolerance specified. The range of nitrate concentrations was between $0.1-12.2 \mathrm{mg} / \mathrm{l}$ with an average nitrate concentration of 1.66 $\mathrm{mg} / \mathrm{l}$. Nitrate concentrations in water bodies are generally relatively low but will be high if the water bodies are contaminated with industrial waste. ${ }^{49}$ The maximum concentration tolerance value according to the 
RASĀYAN J. Chem.

Vol. 14 | No. 4 |2327-2339| October- December | 2021

standard is $50 \mathrm{mg} / \mathrm{l}$. Excess nitrate concentrations can cause diarrhea with blood, convulsions, and gastrointernal (GI) disorders. ${ }^{50}$

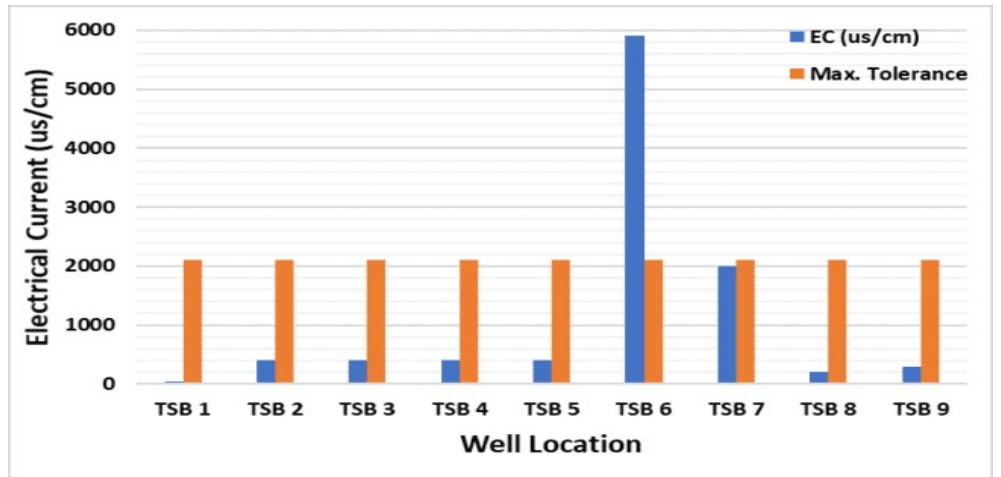

\section{Turbidity}

Fig.-9: Results of Measurement of the Conducted Water Electricity in the Study Area

Turbidity in the form of inorganic substances generally comes from weathered rock and high levels of water turbidity which can protect bacteria from the effects of disinfection. ${ }^{51}$ The standard set for the turbidity value for the use of drinking water raw materials is $5 \mathrm{NTU}$. The turbidity value obtained in the field can be seen in Fig.-11.

Figure 11 shows that three boreholes had turbidity values above the maximum tolerance, namely TSB-5 of 11.6 NTU, TSB-8 of 15.8 NTU, and TSB-9 of 18.8 NTU. The high turbidity value at TSB-8 and TSB-9 is because the locations of the two wells are close to volcanic formations where the lithology of the stratigraphic compiler comes from volcanic pyroclastic materials.

\section{Total Dissolved Solids}

Figure-12 shows that two boreholes had a TDS above the maximum tolerance limit, namely TBS-6 of 2801 $\mathrm{mg} / \mathrm{l}$ and TSB-7 of $1160 \mathrm{mg} / \mathrm{l}$. The field condition informs that these two wells had a brackish taste and smell so they were not used as raw material for drinking water due to the dissolved solids. Water with a high number of dissolved solids or above the maximum tolerance has an unpleasant taste and generally smells, so it is not suitable for consumption as drinking water. ${ }^{52}$ The maximum tolerance limit specified for total dissolved solids is $1,000 \mathrm{mg} / 1$ based on Indonesia standards.

\section{Water Quality Index}

The determination of the water quality index in this termination was based on the object of groundwater research so that the equation needs to be adjusted. Some of the modified parameters of the determination of the weighting were adjusted according to the established standards. Modifications to the NSF WQI analysis parameters can be seen in Table- 4 and the result of the groundwater quality parameter is shown in Table-5.

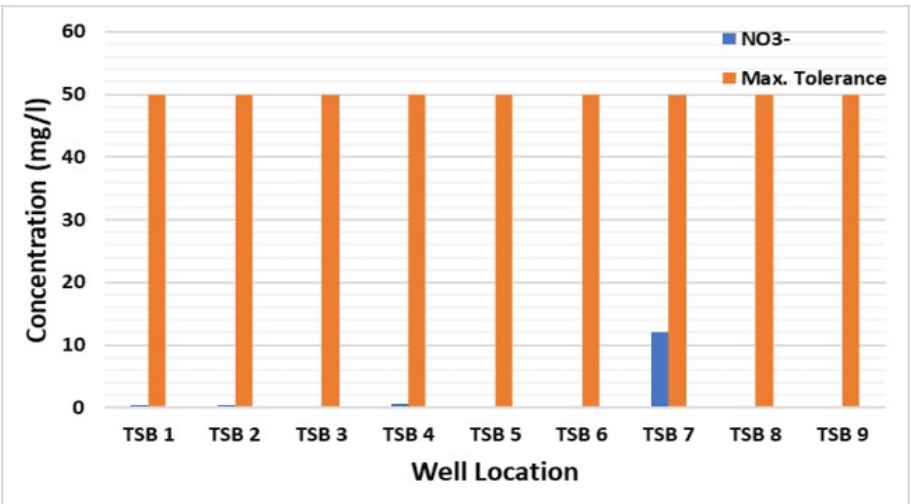

Fig.-10: The Results of the Analysis of Nitrate Concentration at the Study Site 
RASĀYAN J. Chem.

Vol. 14 | No. 4 |2327-2339| October- December | 2021

Table-4: Modification of NSF WQI Analysis Parameters

\begin{tabular}{c|c|c|c|c|c}
\hline No & Parameters & Standard & Modification Parameter & Standard & $\begin{array}{c}\text { Weight } \\
\text { (Wi) }\end{array}$ \\
\hline 1 & Dissolved Oxygen & $4 \mathrm{mg} / 1$ & Mangan & $0.1 \mathrm{mg} / 1$ & 0.17 \\
\hline 2 & Faecal Coliform & $2 / 100 \mathrm{ml}$ & Iron & $0.3 \mathrm{mg} / 1$ & 0.11 \\
\hline 3 & $\mathrm{pH}$ & $6.5-8.5$ & $\mathrm{pH}$ & $6.5-8.5$ & 0.11 \\
\hline 4 & $\mathrm{BOD}$ & $3 \mathrm{mg} / 1$ & Sulphate & $250 \mathrm{mg} / 1$ & 0.10 \\
\hline 5 & Temperature & $\pm 3^{\circ} \mathrm{C}$ & Chloride $^{*}$ & $251 \mathrm{mg} / 1$ & 0.10 \\
\hline 6 & Phosphate & $0.2 \mathrm{mg} / 1$ & Electrical conductivity $*$ & $50 \mathrm{mg} / 1$ & 0.10 \\
\hline 7 & Nitrate & $50 \mathrm{mg} / 1$ & Nitrate & $50 \mathrm{mg} / 1$ & 0.08 \\
\hline 8 & Turgidity & $5 \mathrm{NTU}$ & Turgidity & $5 \mathrm{NTU}$ & 0.07 \\
\hline 9 & Total Solid & $1000 \mathrm{mg} / 1$ & Total Dissolved Solid & $1.000 \mathrm{mg} / \mathrm{l}$ & 0.16 \\
\hline
\end{tabular}

The results from laboratory tests (Table-5) yield the conversion value of the concentration unit into a subindex value so that the values are equivalent to one another. To determine the sub-index value, a sub-index conversion diagram was used (Fig.-3). The sub-index conversion value for each parameter on each TSB can be seen in Table- 6 .

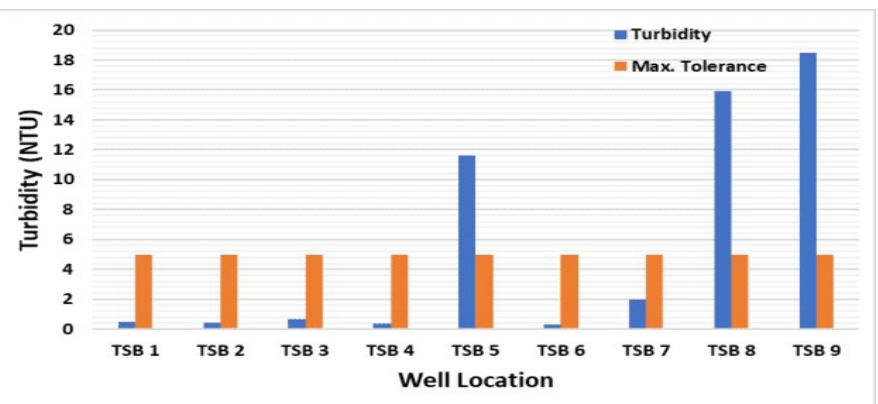

Fig.-11: The Results of calculating the Turbidity Value at the Research Location

Table-5: Laboratory Test Results Data for Groundwater Quality Parameters

\begin{tabular}{c|c|c|c|c|c|c|c|c|c|c}
\hline \multirow{2}{*}{ Parameters } & \multicolumn{7}{|c}{ Data from Lab Test Results for Ground Water Quality Parameters } \\
\cline { 2 - 13 } & TSB-1 & TSB-2 & TSB-3 & TSB-4 & TSB-5 & TSB-6 & TSB-7 & TSB-8 & TSB-9 & $\begin{array}{c}\text { Quality } \\
\text { Standard }\end{array}$ \\
\hline Sulfat $(\mathrm{mg} / \mathrm{I})$ & 0.01 & 0.01 & 4 & 0.01 & 7 & 51 & 70 & 24 & 8.01 & 250 \\
\hline $\mathrm{pH}$ & 6.8 & 7.4 & 7.1 & 7.2 & 7.3 & 6.2 & 6.8 & 7.6 & 7.35 & $6.5-8.5$ \\
\hline EC $(\mu / \mathrm{cm})$ & 26 & 335 & 291 & 291 & 328 & 5787 & 2011 & 196 & 236 & 2250 \\
\hline Mangan $(\mathrm{mg} / \mathrm{I})$ & 0.9 & 0.2 & 0.3 & 0.1 & 0.1 & 3.3 & 1.2 & 7.776 & 0.01 & 0.1 \\
\hline Besi $(\mathrm{mg} / \mathrm{I})$ & 0.2 & 0.2 & 0.2 & 0.2 & 0.2 & 0.2 & NA & NA & 0.06 & 0.3 \\
\hline Nitrat $(\mathrm{mg} / \mathrm{I})$ & 0.7 & 0.4 & 0.2 & 0.6 & 0.01 & 0.4 & 12.2 & 0.1 & 0.409 & 50 \\
\hline Turbiditas $(\mathrm{NTU})$ & 0.62 & 0.44 & 1.08 & 0.41 & 11.6 & 0.46 & 2.1 & 15.8 & 18.8 & 5 \\
\hline TDS $(\mathrm{mg} / \mathrm{I})$ & 655 & 155 & 146 & 140 & 167 & 2801 & 1160 & 89 & 130 & 1000 \\
\hline Klorida $(\mathrm{mg} / \mathrm{I})$ & 0.27 & 0.01 & 0.04 & 0.02 & 0.01 & 4.12 & 3.67 & 71 & 4.37 & 250 \\
\hline
\end{tabular}

When the sub-index values for each parameter have been known, the weight calculation was carried out (Table-2). The results of the calculation called Bobbitt parameters can be seen in Table-7.

The result of the NSF WQI analysis for each TSB can be seen in Table-8. It can be concluded that groundwater in the study area is in the moderate to excellent category. In TSB-1 based on the NSF WQI analysis, the groundwater conditions at that location were in a good category. The eight parameters analyzed at this location were below the maximum tolerances specified. While one parameter, manganese, had a concentration above the specified maximum tolerance. Field observations informed that although the TSB1 location is close to the coast (about a kilometer from the shoreline), this water condition is odorless and tasteless. Groundwater conditions in TSB-2 were in an excellent category. In this area, eight parameters were below the maximum specified tolerance, while one parameter, i.e., manganese, was above the specified maximum tolerance.

The location of this well has a distance of $1.33 \mathrm{~km}$ from the shoreline and has a distance of $0.5 \mathrm{~km}$ to TSB1, the water conditions at TSB-2 were identical to TSB-1, namely odorless and tasteless. In TSB-3, the 2335

GROUNDWATER QUALITY: STUDY OF THE JEUNIB BASIN

Muhammad Irham et al. 
RASĀYAN J. Chem.

Vol. 14 | No. 4 |2327-2339| October- December | 2021

water condition was in the excellent category. Eight parameters were below the maximum tolerance limit, while manganese was above the specified maximum tolerances. The water at TSB-3 was odorless, tasteless, and colorless.

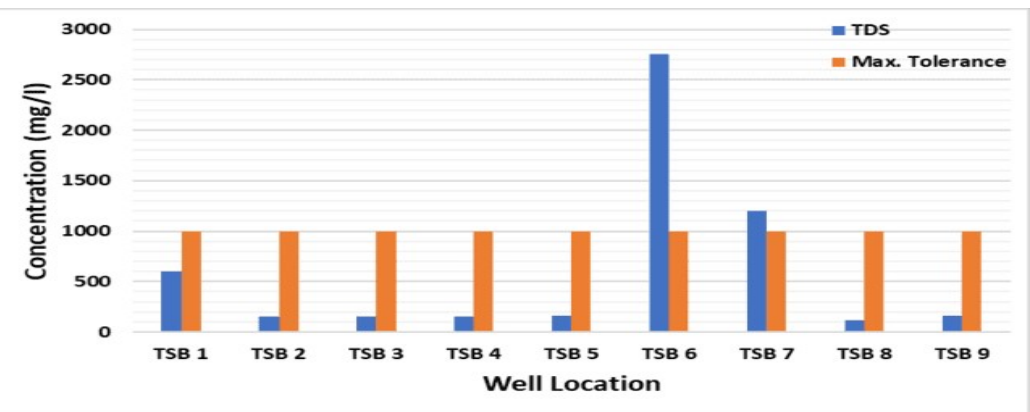

Fig.-12: The Value of Total Dissolved Solids at the Study Site

Table-6: Subindex Value of each Parameter

\begin{tabular}{|c|c|c|c|c|c|c|c|c|c|}
\hline \multirow{2}{*}{ Parameters } & \multicolumn{9}{|c|}{ Parameters Sub Index Value } \\
\hline & TSB-1 & TSB-2 & TSB-3 & TSB-4 & TSB-5 & TSB-6 & TSB-7 & TSB-8 & TSB-9 \\
\hline Sulfat (mg/I) & 100 & 100 & 100 & 100 & 99 & 80 & 72 & 89 & 99 \\
\hline $\mathrm{pH}$ & 81 & 93 & 92 & 92 & 93 & 57 & 81 & 93 & 93 \\
\hline $\mathrm{EC}(\mu / \mathrm{cm})$ & 100 & 86 & 87 & 87 & 86 & 0 & 20 & 93 & 88 \\
\hline Mangan (mg/I) & 43 & 72 & 72 & 90 & 90 & 30 & 36 & 24 & 100 \\
\hline $\operatorname{Besi}(\mathrm{mg} / \mathrm{I})$ & 85 & 85 & 85 & 85 & 85 & 85 & 0 & 0 & 87 \\
\hline Nitrat $(\mathrm{mg} / \mathrm{I})$ & 100 & 100 & 100 & 100 & 100 & 100 & 46 & 100 & 100 \\
\hline Turbiditas (NTU) & 100 & 100 & 100 & 100 & 72 & 100 & 100 & 68 & 59 \\
\hline TDS (mg/I) & 0 & 78 & 78 & 79 & 76 & 0 & 0 & 85 & 80 \\
\hline Klorida $(\mathrm{mg} / \mathrm{I})$ & 100 & 100 & 100 & 100 & 100 & 100 & 100 & 74 & 100 \\
\hline
\end{tabular}

TSB-4 had an excellent category of water condition, where all parameters were below the maximum tolerance specified and the water at this location was odorless, tasteless, and colored. The water condition at TSB-5 shows the groundwater quality index was in the excellent category. 8 parameters were below the specified tolerance value, while the turbidity value was above the specified maximum tolerance. The water conditions at this location were odorless, tasteless, and colorless. In TSB-6, groundwater conditions were in the moderate category. Tt this location, there were 5 parameters, such as iron, sulphate, chloride, nitrate and turbidity which were still below the maximum tolerance value specified, while 4 parameters such as electrical conductivity, manganese, $\mathrm{pH}$ and the number of dissolved solids were above the specified maximum tolerance value. The groundwater conditions at this location were salty, odorless and colorless, so they are only used for ablution purposes.

Table-7: Calculation Results of Parameter Subindex Values with Parameter Weights

\begin{tabular}{c|c|c|c|c|c|c|c|c|c}
\hline \multirow{2}{*}{ Parameters } & \multicolumn{7}{|c}{ WQI Parameters $=\{$ Wi (Parameters) $x$ Qi (Parameters) } \\
\cline { 2 - 11 } & TSB-1 & TSB-2 & TSB-3 & TSB-4 & TSB-5 & TSB-6 & TSB-7 & TSB-8 & TSB-9 \\
\hline Sulfat $(\mathrm{mg} / \mathrm{I})$ & 17.00 & 17.00 & 17.00 & 17.00 & 16.83 & 13.60 & 12.24 & 15.13 & 16.83 \\
\hline $\mathrm{pH}$ & 8.91 & 10.23 & 10.12 & 10.12 & 10.23 & 6.27 & 8.91 & 10.23 & 10.23 \\
\hline $\mathrm{EC}(\mu / \mathrm{cm})$ & 11.00 & 9.46 & 9.57 & 9.57 & 9.46 & 0.00 & 2.20 & 10.23 & 9.68 \\
\hline Mangan $(\mathrm{mg} / \mathrm{I})$ & 4.30 & 7.20 & 7.20 & 9.00 & 9.00 & 3.00 & 3.60 & 2.40 & 10.00 \\
\hline Besi $(\mathrm{mg} / \mathrm{I})$ & 8.50 & 8.50 & 8.50 & 8.50 & 8.50 & 8.50 & 0.00 & 0.00 & 8.70 \\
\hline Nitrat $(\mathrm{mg} / \mathrm{I})$ & 10.00 & 10.00 & 10.00 & 10.00 & 10.00 & 10.00 & 4.60 & 10.00 & 10.00 \\
\hline Turbiditas $(\mathrm{NTU})$ & 8.00 & 8.00 & 8.00 & 8.00 & 5.76 & 8.00 & 8.00 & 5.44 & 4.72 \\
\hline TDS $(\mathrm{mg} / \mathrm{I})$ & 0.00 & 5.46 & 5.46 & 5.53 & 5.32 & 0.00 & 0.00 & 5.95 & 5.60 \\
\hline Klorida $(\mathrm{mg} / \mathrm{I})$ & 16.00 & 16.00 & 16.00 & 16.00 & 16.00 & 16.00 & 16.00 & 11.84 & 16.00 \\
\hline
\end{tabular}

The water condition at TSB-7 was in the moderate category. At this location, there was no solubility test for iron, so the sub-index value was made to zero. At this location, there were also 2 parameters, namely the number of dissolved solids and manganese which exceeded the specified maximum tolerance value, while other parameters such as turbidity, $\mathrm{pH}$, nitrate, chloride and electrical conductivity did not exceed the 
specified maximum tolerance limit. The water condition at TSB-8 was in a good category. At this location, there was also no laboratory test on iron content so that the subindex value was considered zero. At this location, there were 7 parameters such as electrical conductivity, the number of dissolved solids, nitrate, chloride and sulphate which were still below the standards set, while the other two parameters such as manganese and turbidity exceeded the specified maximum tolerance limits. Groundwater conditions in TSB-9 were in the excellent category. At this location, 8 parameters such as iron content, electrical conductivity, sulphate, chloride, manganese, $\mathrm{pH}$ and the number of dissolved solids were still below the specified maximum tolerance value, while the turbidity exceeded the specified maximum tolerance value.

Table-8. Water Quality Index for each TSB

\begin{tabular}{c|c|l}
\hline Location & $\begin{array}{c}\text { Water Quality Index } \\
\text { (NSF WQI) }\end{array}$ & Result \\
\hline TSB-1 & 83.71 & Good \\
\hline TSB-2 & 91.85 & Excellent \\
\hline TSB-3 & 91.85 & Excellent \\
\hline TSB-4 & 93.72 & Excellent \\
\hline TSB-5 & 91.10 & Excellent \\
\hline TSB-6 & 65.37 & Moderate \\
\hline TSB-7 & 55.55 & Moderate \\
\hline TSB-8 & 71.22 & Good \\
\hline TSB-9 & 91.76 & Excellent \\
\hline
\end{tabular}

\section{Geological Relations and Groundwater Conditions}

Once groundwater passes through rocks or soil, it will cause the dissolution of minerals in the rock, resulting in changes in the chemical content of groundwater according to the rocks in which it passes ${ }^{53}$. Based on chemical analysis and the chemical properties of groundwater, the type of groundwater understudy can be determined. Based on geological maps, the location of the wells in the study area is in the alluvium unit of the alluvium formation which is strengthened based on the analysis of groundwater typology and groundwater chemical facies. Analysis of groundwater typology shows that groundwater is in the typology of the alluvial coastal sediment aquifer system with confined aquifer conditions. The constituent material of this lithology is in the form of clastic sediments (loose material) such as clay, sandy loam, gravel sand and sand. At the research location, groundwater has experienced an increase in salinity resulting in a salty taste, besides that the electrical conductivity and the number of dissolved solids at both locations show quite high numbers (see explanation on TSB-6 and TSB-7).

The concentration of manganese content in all TSB tends to be directly proportional to the value of its electrical conductivity; the manganese content is interpreted as a mineral formed in sedimentary rocks. In several locations that tend to be close to agglomerate geological units or tuff rocks, such as TSB-5, TSB-8 and TSB-9, the turbidity has a high enough value. This is interpreted as a result of the interaction of groundwater with pyroclastic material (agglomerate and tuff).

\section{CONCLUSION}

The groundwater aquifer in the study area geologically exists in an alluvium unit with a coastal alluvial sediment type of aquifer system confined with $\mathrm{Ca}-\mathrm{HCO}_{3}$ and $\mathrm{Mg}-\mathrm{SO}_{4}$ facies aquifer. Groundwater quality in the research location was at the moderate, good and excellent categories. The moderate category was TSB 6, the good water quality category was TSB-1, TSB-7 and TSB-8, while the excellent category was TSB-2, TSB-3, TSB-4, TSB-5 and TSB-9.

\section{ACKNOWLEDGMENT}

We would like to thanks to Department of Geological Engineering of Engineering Faculty and Geographical Information System Laboratory of Marine and Fisheries Science of Syiah Kuala University for their permission and support for this research.

\section{REFERENCES}

1. M. Sturm, M.A. Goldstein and C.Parr, Water Resources Research, 53(5), 3534(2017), https://doi.org/10.1002/2017WR020840 
RASĀYAN J. Chem.

Vol. 14 | No. 4 |2327-2339| October- December | 2021

2. A.A. Cronin, M. Odagiri, B. Arsyad, M.T. Nuryetty, G. Amannullah, H. Santoso, K. Darundiyah, International Journal of Hygiene and Environmental Health, 220(7), 1141(2017), https://doi.org/10.1016/j.ijheh.2017.07.001

3. H. Wang, J. Xu, L. Sheng, L. Ma, X. Liu, Arabian Journal of Geoscience, 13(2), 1(2020), https://doi.org/10.1007/s12517-020-5087-4

4. G, Kang, J.Z. Gao, G. Xie, Institute of Electrical Electronics Engineers (IEEE) Third International Conference on Big Data Computing Service and Applications, 224-232 (2017), https://doi.org/10.1109/BigDataService.2017.40

5. P. Luo, S. Kang, M. Zhou, J. Lyu, S. Aisyah, M. Binaya, R.K. Regmi, D. Nover, PLoS One, 14(7), e0219009 (2019), https://doi.org/10.1371/journal.pone.0219009

6. E.R. Kelly, R. Cronk, E. Kumpel, G. Howard, J. Bartram, Science of The Total Environment, 718, 137237 (2020), https://doi.org/10.1016/j.scitotenv.2020.137237

7. P. Li, R. Tian, C. Xue, J. Wu, Environmental Science and Pollution Research, 24(15),13224(2017), https://doi.org/10.1007/s11356-017-8753-7

8. E. Sumarga, Tropical Conservation Science, 10, 1940082917706168 (2017), https://doi.org/10.1177/1940082917706168

9. P. Kumar, Y. Masago, B.K. Mishra, S. Jalilov, A.R. Emam, M. Kefi, K. Fukushi, Water, 9(6), 410 (2017), https://doi.org/10.3390/w9060410

10. H. Marhaento, M.J. Booij, A.Y. Hoekstra, Hydrology Research, 48(4), 1143(2017), https://doi.org/10.2166/nh.2016.110

11. T.T. Putranto, A.H. Qadarisman, N. Santi, N. Najib, Environment, Energy and Earth Sciences (E3S) Web of Conferences, 73, 4024 (2018), https://doi.org/10.1051/e3sconf/20187304024

12. O. Setiawan, J. Sartohadi, M.P. Hadi, D. Mardiatno, Acta Geophysica, 67(1), 177(2019), https://doi.org/10.1007/s11600-018-00244-4

13. S. Nabila, E. Kusratmoko, K. Marko, IOP Conference Series: Earth and Environmental Science, 561, 12030 (2020), https://doi.org/10.1088/1755-1315/561/1/012030

14. H. Heru, V.A. de Sousa Vicente, Prosiding Seminar Nasional Kebumian Ke-6 Teknik Geologi Universitas Gadjah Mada, (2013).

15. M. Irpan, Electronic Thesis and Dissertation Universitas Syiah Kuala, 2019.

16. R.D.M. Ujianti, S. Anggoro, A.N. Bambang, F. Purwanti, Journal of Physics: Conference Series, 1025, 12037 (2018), https://doi.org/10.1088/1742-6596/1025/1/012037

17. P. Vijayalakshmi, M. Abraham, Rasayan Journal of Chemistry, 11(2), 728(2018), http://dx.doi.org/10.31788/RJC.2018.1122051

18. M. Tripathi, S.K. Singal, Ecological Indicators, 96, 430(2018), https://doi.org/10.1016/j.ecolind.2018.09.025

19. A.L. Hoya, N. Yuliastuti, Sudarsono, Seminar Nasional Lahan Suboptimal, 1, 47(2020).

20. R. Iserhien-Emekeme, M.O. Ofomola, M. Bawallah, O. Anomohanran, Hydrology, 4(3), 42(2017), https://doi.org/10.3390/hydrology4030042

21. V.B.B Patil, S.M. Pinto, T. Govindaraju, V.S. Hebbalu, V. Bhat, L.N. Kannanur, Environmental Geochemistry and Health, 42(9), 2667(2020), https://doi.org/10.1007/s10653-019-00500-6

22. S. Park, S-Y. Hamm, H-T. Jeon, J. Kim, Sustainability, 9(7), 1157(2017). https://doi.org/10.3390/su9071157

23. K. Prabhu, R. Sivakumar, Rasayan Journal of Chemistry, 11(2), 735(2018), https://doi.org/10.31788/RJC.2018.1121837

24. R.P. Poetra, T.N Adji, L.W. Santosa, N. Khakhim, Aquatic Geochemistry, 26(4), 421(2020), https://doi.org/10.1007/s10498-020-09384-w

25. N. Adimalla, P. Li, S. Venkatayogi, Environmental Processes, 5(2), 363(2018), https://doi.org/10.1007/s10040-017-1646-5

26. S. Gaikwad, S. Gaikwad, D. Meshram, V. Wagh, A. Kandekar, A. Kadam, Environment, Development and Sustainability, 22(3), 2591(2020), https://doi.org/10.1007/s10668-019-00312-9

27. K. Lezzaik, A. Milewski, Hydrogeology Journal, 26(1), 251(2018), https://doi.org/10.1007/s10040017-1646-5

GROUNDWATER QUALITY: STUDY OF THE JEUNIB BASIN 
RASĀYAN J. Chem.

Vol. 14 | No. 4 |2327-2339| October- December | 2021

28. R. Slabe-Erker, T. Bartolj, M. Ogorevc, D. Kavaš, K. Koman, Ecological Indicator, 73, 338(2017), https://doi.org/10.1016/j.ecolind.2016.09.048

29. A. Bouderbala, B.Y. Gharbi, Environmental Earth Sciences, 76(21), 1(2017), https://doi.org/10.1007/s12665-017-7067-x

30. H. Wei, X. Liang, Environment, Energy and Earth Sciences (E3S) Web of Conferences: Édition Diffusion Presse (EDP) Sciences, 98, (2019), https://doi.org/10.1051/e3sconf/20199809031

31. P. Balamurugan, P.S. Kumar, K. Shankar, Data in Brief, 29, 105255(2020), https://doi.org/10.1016/j.dib.2020.105255

32. B.S. Meena, N. Bhargava, Rasayan Journal of Chemistry, 5(4), 438(2012).

33. C. Postigo, D.E. Martinez, S. Grondona, K.S.B. Miglioranza, Encyclopedia of the Anthropocene, 5(5), 67(2018), https://doi.org/10.1016/B978-0-12-809665-9.09880-3

34. H. Ghahremanzadeh, R. Noori, A. Baghvand, T. Nasrabadi, Environment Geochemistry and Health, 40(4), 1317(2018), https://doi.org/10.1007/s10653-017-0058-8

35. A. Lkr, M.R. Singh, N. Puro, Applied Water Science, 10(1), 1(2020), https://doi.org/10.1007/s13201019-1133-3

36. S.H. Ewaid, S.A. Abed, The Egyptian Journal of Aquatic Research, 43(2), 117(2017), https://doi.org/10.1016/j.ejar.2017.03.001

37. Ş. Şener, E. Şener, A. Davraz, Science of the Total Environment, 584, 131(2017), https://doi.org/10.1016/j.scitotenv.2017.01.102

38. D. Sutjiningsih, International Journal of Technology, 1, 145(2017), https://doi.org/10.14716/ijtech.v8i1.3971

39. R.M. Cristable, E. Nurdin, W. Wardhana, IOP Conference Series: Earth and Environmental Science, 481, 12068 (2020), https://doi.org/10.1088/1755-1315/481/1/012068

40. P. Pohan, D.A. Saleh, B. Budiyono, S. Syafrudin Jurnal Ilmu Lingkungan, 14(2), 63(2016), https://doi.org/10.14710/jil.14.2.63-71

41. R. Mede, M. Klein, R.A. Claus, S. Krieck, S. Quickert, H. Görls, U. Neugebauer, M. Schmitt, G. Gessner, S.H. Heinemann, Inorganic Chemistry, 55(1), 104(2016), https://doi.org/10.1021/acs.inorgchem.5b01904

42. J. Hu, H. Dong, Q. Xu, W. Ling, J. Qu, Z. Qiang, Water Research, 129, 428(2018), https://doi.org/10.1016/j.watres.2017.10.065

43. S.C. Izah, N. Chakrabarty, A.L. Srivastav, Exposure and Health, 8(2), 285(2016). https://doi.org/10.1007/s12403-016-0195-9

44. C.E. Enyoh, A.W. Verla, N.J. Egejuru, Journal of Environmental Analytical Chemistry, 5(2), 1(2018), https://doi.org/10.4172/2380-2391.1000238

45. R.J. Hunt, W.P. Johnson, Hydrogeology Journal, 25(4), 921(2017), https://doi.org/10.1021/es960670y

46. C. Singaraja, Applied Water Science, 7(5), 2157(2017), https://doi.org/10.1007/s13201-017-0594-5

47. D.P.E. Putra, D. Halim, S.S. Widagdo, R.S.S. Atmaja, Journal Degraded Mining Lands Management, 8(1), 2525 (2020), https://doi.org/10.15243/jdmlm.2020.081.2525

48. N. Adimalla, A.K. Taloor, Groundwater for Sustainable Development, 10, 100288(2020), https://doi.org/10.1016/j.gsd.2019.100288

49. M.S. Rishi, L. Kaur L, S. Sharma, Human Ecological Risk Assessment: An International Journal, 26(10), 2716(2020), https://doi.org/10.1080/10807039.2019.1682514

50. S. Khan, M. Shahnaz, N. Jehan, S. Rehman, M.T. Shah, I. Din, Journal Cleaner Production, 60, 93(2013), https://doi.org/10.1016/j.jclepro.2012.02.016

51. H.A. Jawadi, J. Sagin, D.D. Snow, Water, 12(10), 2890 (2020), https://doi.org/10.3390/w12102890

52. A.F. Rusydi, IOP Conference Series: Earth and Environmental Science, 118, 12019(2018), https://doi.org/10.1088/1755-1315/118/1/012019

53. S.P. Rajaveni, K. Brindha, L. Elango Applied Water Science, 7(3), 1377(2017), https://doi.org/0.1007/s13201-015-0327-6

[RJC-6454/2021] 